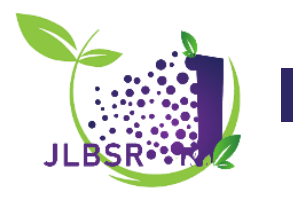

\title{
Electrofusion of Mesophyll Protoplasts From Two Varieties of Sugar Beet, (Beta vulgaris L.)
}

\author{
Qutaiba. S. AL-Nema*, Mozahim K. AL-Mallah \\ Laboratory of Plant Genetic Manipulation, Dept. of Biology, College of Education for Pure Sciences, University of Mosul, Iraq. \\ (dr.qutaibashuaib@uomosul.edu.iq, mozahim_kasim52@yahoo.com) \\ *Correspondence: dr.qutaibashuaib@uomosul.edu.iq
}

\begin{abstract}
Somatic hybridization between different plants through protoplast fusion represent an efficient experimental approach to produce genetically transformed plant species. Electrofution of mesophyll protoplasts in sugar beet was occurred to overcome the barriers faced breeding program of this economically industrial crop Protoplasts were successfully isolated from leave's mesophyll of two varieties of sugar beet (Beta vulgaris L.). Various enzyme solutions were assessed for the cell wall degrading ability. They express different efficiency in isolation of mesophyll protoplasts of var. Baraka. The protoplasts yield was $18 \times 104 \mathrm{cell}^{-1} \mathrm{msing}^{-1} \mathrm{me} \mathrm{mixture} \mathrm{consisting}$ of $0.5 \%$ Cellulase RS, $1.0 \%$ Hemicellulase and $0.1 \%$ Pectolyase Y-23 with $13 \%$ mannitol. A total of 16 hrs. for cell wall digestion, and protoplast viability approached $93 \%$. Protoplasts were isolated from leaf mesophyll of var. Carola using the same enzymatic mixtures. High protoplasts yield $20 \times 10^{4}$ cell $\mathrm{ml}^{-1}$ was obtained, requiring the same period 16 hrs. to approach viability $96 \%$. The protoplasts were spherical in shape, varied in chloroplast distribution, having size ranged $12-52 \mu \mathrm{m}$. The present study succeded in electrofusion between Baraka $\times$ Carola mesophyll protoplasts, producing somatic hybrid cells under conditions of $1 \mathrm{MHz}^{1000} \mathrm{Vcm}^{-1}, 2$ pulses, 1.5 msec./pulse with fusion percent of $73 \%$.
\end{abstract}

Keywords: Somatic Hybridization, Protoplasts, Beta vulgaris, Electrofusion, Sugar Beet

Received: February 26 th, 2020 /Accepted: April 20th, 2020 /Online: April $23^{\text {rd }}, 2020$

Protoplasts fusion considered as one of the important possibilities to obtain hybrid plants with novel characters particularly in plant species facing difficulties in breeding program (Power et al., 1989). The first successful fusion was made between vacuolated protoplasts of corn Zea mays L. and the non-vacuolated protoplasts of oat, Avena sativa L. (Power et al., 1970). Utilization of electrical pulse in protoplast fusion initiated in 1979 (Senda et al., 1979). Somatic hybridization between different plants through protoplast fusion represent an efficient experimental approach to produce genetically transformed plant species, such as transfer of herbicides resistance in cereals, including rice (Rathore et al., 1993; Davey and Anthony, 2010), production of hybrids from protoplasts fusion of Citrus sinensis L. with $C$. paradise L. (Guo et al., 2000), and potato plants resistant to early blight disease (Szczerbakowa et al., 2001). This plant system benefits direct uptake gene in protoplasts by electroporation method (Niedz et al., 2003) or chemical factor such as poly ethylene glycol PEG (Mi Jeon et al., 2007).

\section{INTRODUCTION}

The aim of this investigation was to overcome the barriers faced breeding program of this economically industrial crop, which cannot be achieved through other conventional breeding methods, through the production of somatic hybrids, through Electrofution of mesophyll protoplasts in sugar beet.

\section{MATERIALS AND METHODS}

\section{A. Seeds Source and Surface Sterilization}

Sample of 100 seeds of each variety "Baraka and Carola" of sugar beet, Beta vulgaris L. (obtained from the General Enterprise for Sugar Industry, Mosul-Iraq) were soaked in $20 \mathrm{ml}$ of 3\% sodium hypochlorite solution (Commercial bleach, Babylon Comp. for Detergent, Baghdad), for 30 minutes The treated seeds were washed thoroughly with autoclaved water (Ritchie et al., 1989).

\section{B. Seeds Germination}

Surface sterilized seeds of each variety were divided into five groups. Two sets of sugar beet seed were cultured on the surface of agar-solidified AH (Arnon and Hoagland, 1944) and MS (Murashig and Skoog, 1962) media. Other seed sets were saw in water

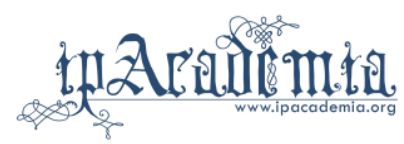


agar, peat-moss and vermiculite. Samples were incubated in growth chamber conditions (AL-Nema and AL-Mallah, 2013).

\section{Isolation of Mesophyll Protoplasts}

Leaves were excised from 6 weeks old sugar beet axenic seedlings for each variety. Lower epidermis were peeled by fine forceps, then leaves cut into small portion of $2.0 \mathrm{~mm}^{2}$ and incubated into $10 \mathrm{ml} \mathrm{CPW} \mathrm{13M}$ solution (Frearson et al., 1973) for one hour in dark. Different enzyme mixtures (Table 1) were tested for protoplast isolation.

Table 1. Enzymes solutions utilized in isolation of protoplasts from leaf mesophyll of axenic sugar beet (Beta vulgaris L.) seedlings.

\begin{tabular}{|l|c|c|c|c|c|c|c|c|c|}
\hline \multirow{2}{*}{ Enzyme name } & \multicolumn{7}{|c|}{ Enzyme solutions (\%) } \\
\cline { 2 - 10 } & I & II & III & IV & V & VI & VII & VIII & IX \\
\hline Cellulase R10 & 2.0 & 2.0 & 0.5 & 1.0 & 0.0 & 0.0 & 0.0 & 0.0 & 0.0 \\
\hline Cellulase RS & 1.0 & 1.5 & 0.5 & 0.0 & 1.0 & 1.0 & 2.0 & 2.0 & 0.5 \\
\hline Cellulysin & 0.0 & 0.0 & 0.0 & 0.0 & 0.1 & 0.5 & 0.1 & 0.5 & 0.0 \\
\hline Driselase & 0.0 & 0.0 & 0.0 & 0.0 & 0.1 & 0.0 & 0.1 & 0.0 & 0.0 \\
\hline Hemicellulase & 0.0 & 0.0 & 0.0 & 0.0 & 0.0 & 0.0 & 0.0 & 0.0 & 1.0 \\
\hline Macerozym R10 & 0.5 & 1.0 & 0.0 & 0.0 & 0.0 & 0.0 & 0.0 & 0.0 & 0.0 \\
\hline Pectinase & 0.0 & 0.0 & 0.0 & 0.0 & 0.1 & 0.1 & 0.1 & 0.1 & 0.0 \\
\hline Pectolyase Y-23 & 0.1 & 0.1 & 0.1 & 0.1 & 0.0 & 0.0 & 0.0 & 0.0 & 0.1 \\
\hline Mannitol & 9.0 & 9.0 & 4.0 & 4.0 & 9.0 & 9.0 & 9.0 & 9.0 & 13 \\
\hline
\end{tabular}

Samples of mesophyll tissue were incubated in each enzyme mixture ( at ratio of $100 \mathrm{mg} / 1.0 \mathrm{ml}$ ) in plastic Petri-dishes $(9.0 \mathrm{~cm}$ diameter, Sterilin, UK), they placed on orbital shaking incubator at $40 \mathrm{rpm}$ for 16-24 hrs. Enzymes mixtures containing the released protoplasts were passed through nylon sieve ( $80 \mu \mathrm{m}$, PGMG, Nott. Univ., UK), and distributed in covered test tubes of $10 \mathrm{ml}$ volume, centrifuged (Centaur 2, MES, England) at $100 \mathrm{~g}$ for $5.0 \mathrm{~min}$. The supernatant was discard and $5.0 \mathrm{ml}$ of CPW $13 \mathrm{M}$ was added to the precipitated protoplasts. This step was repeated 2-3 times with replacing the washing solution by addition of liquid medium. Then protoplasts was resuspended in $2.0 \mathrm{ml}$ of KM8p (Power et al., 1989; AL-Nema and AL-Mallah, 2013).

\section{Determination of Mesophyll Protoplasts Properties}

Small volume $(0.2 \mathrm{ml}$ each) of protoplasts suspension was used to determine viability using FDA stain (Power et al., 1989). While cell wall regeneration was detected using calcofluor white (Galbraith, 1981). Nucleation of the protoplasts was carried out using carbol fuchsin (Kao, 1975).

\section{Electrofusion of Baraka $\times$ Carola protoplasts}

Electrofusion between the two protoplasts was carried out as described by Jones et al. (1994) in Labs. of PGMG/Plant and Crop Sciences Division., Nottingham University, UK. The amount of $2.0 \mathrm{ml}$ of each protoplast was placed in a separate test tube $(10 \mathrm{ml}$ volume $)$ and add to each $5.0 \mathrm{ml}$ of the fusion solution EFM 13, centrifuged at $100 \mathrm{~g}$ for 5.0 min. to wash up the protoplasts for three times. The two suspension were mixed in one tube and the densities $2 \times 10^{4}$, $3 \times 10^{4}$ and $5 \times 10^{4}$ protoplast $/ \mathrm{ml}$ were provided. The amount of $1.0 \mathrm{ml}$ from each density was transferred to the wells of the 25 wells Petri dish (Sterilin, UK). The sterile electrode was fixed on the well containing protoplasts suspension and the dish was examined the dish by microscope (Nikon DS Fi1, Japan) for monitoring. The electrical fusion apparatus swiched on. When protoplast arranged in chain, the AC current was reduced to zero then the interested voltage of DC current was run to induce fusion of protoplasts. After removeing the electrode, sterilize washed and place on the other wells. Finally, $1.0 \mathrm{ml}$ of CPW 13M was added to each electrotreated protoplasts mixture and kept for 1.0 hour. Later, the EF solutions was removed from each wells and protoplasts transfered to test tube, then centrifuged at $100 \mathrm{~g}$ for 5.0 minutes, The precipitated fused and non-fused protoplasts were resuspended into $20 \mathrm{ml}$ of liquid KM8p medium to be ready for culture.

Picking - up fused protoplasts and culture by embedding in agar Visual selection method by Power et al. (1989) was followed in picking-up fused protoplasts using micromanipulator. This method depends on the size of fused protoplasts.

A total of $2.0 \mathrm{ml}$ of fused protoplast was prepared at the density of $5 \times 10^{4}$ protoplast / $\mathrm{ml}$ in KM8p medium. Similar volumes of $1.6 \%$ sterile and molted agarose (Sea plaque agarose, Sigma, UK) were kept at $45^{\circ} \mathrm{C}$ in water-bath. The two volumes were mixed carefully then distributed into drops of identical sizes on the bottom of $5.0 \mathrm{~cm}$ diameter plastic Petri dishes ( 5 drops/dish). After the solidification of drops, $4.0 \mathrm{ml}$ of liquid KM8p medium was added to each dish, covered with lids and closed by nescofilm strip. Dishes were incubated in $25^{\circ} \mathrm{C}$ and diffused light 100 Lux conditions (Davey et al., 2010).

\section{RESULTS}

\section{A. Production of Sterile Seedlings}

Data indicate that $\mathrm{NaOCl}$ was efficient in surface sterilization of sugar beet seeds to produce sterile seeds and vermiculite was the most suitable for axenic seedlings production (Table 2).

\section{B. Mesophyll Protoplasts Isolation}

The results referred to the isolation of mesophyll protoplasts from leaves of axenic seedlings of variety "Baraka", and eight of nine enzyme mixtures were succeeded in isolation process.

Similarly, mesophyll protoplasts was isolated from leaves of Carola seedlings, and data proved that six of the same nine enzyme mixtures were sustained the isolation. Yield and viability of these protoplasts are summarized in (Table 3). 


\section{Electrical Fusion of Baraka $\times$ Carola Mesophyll Protoplasts}

The results proved the incidence of fusion between protoplasts of the two varieties and protoplasts density was a determinant factor in fusion process which approached 43$73 \%$ (Table 4). This percentage affected by factors of fusion solution and fusion conditions which controlled the number of fused cells.

Table 2. Seeds germination and axenic seedlings production of the two varieties of sugar beet (Beta vulgaris $\mathrm{L}$.) in different media.

\begin{tabular}{|c|c|c|c|c|c|}
\hline Variety & $\begin{array}{c}\text { Culture } \\
\text { media }\end{array}$ & $\begin{array}{c}\text { Germination } \\
(\%)\end{array}$ & $\begin{array}{c}\text { Interval } \\
(\text { day })\end{array}$ & $\begin{array}{c}\text { Leave } \\
\text { number }\end{array}$ & $\begin{array}{c}\text { Seedling } \\
\text { condition }\end{array}$ \\
\hline \multirow{4}{*}{ Baraka } & MS & 4.0 & 15 & 2 & Weak \\
\cline { 2 - 6 } & AH & - & - & - & - \\
\cline { 2 - 6 } & Peat moss & 74 & 7.0 & 2 & Good \\
\cline { 2 - 6 } & Water agar & 48 & 15 & 2 & Medium \\
\cline { 2 - 6 } & Vermiculate & 88 & 4.0 & 4 & V. good \\
\hline \multirow{4}{*}{ Carola } & MS & - & - & - & - \\
\cline { 2 - 6 } & AH & 64 & 10 & 2 & Medium \\
\cline { 2 - 6 } & Peat moss & 43 & 7.0 & 4 & Good \\
\cline { 2 - 6 } & Water agar & 38 & 15 & 2 & Medium \\
\cline { 2 - 6 } & Vermiculate & 81 & 4.0 & 4 & V. good \\
\hline
\end{tabular}

Number of seeds 100/medium, (-) No germination

Table 3. Efficiency of enzyme mixtures used in isolation of mesophyll protoplasts from leaves of varieties Baraka and Carola of sugar beet (Beta vulgaris $\mathrm{L}$.$) .$

\begin{tabular}{|c|c|c|c|c|c|c|}
\hline \multirow{2}{*}{$\begin{array}{c}\text { Enzyme } \\
\text { mixture }\end{array}$} & \multicolumn{2}{|c|}{$\begin{array}{c}\text { Duration } \\
(\mathrm{h})\end{array}$} & \multicolumn{2}{c|}{$\begin{array}{c}\text { Yield } \\
\left(\times 10^{4} \text { prot. } / \mathrm{ml}\right)\end{array}$} & \multicolumn{2}{|c|}{$\begin{array}{c}\text { Viability } \\
(\%)\end{array}$} \\
\cline { 2 - 7 } & Baraka & Carola & Baraka & Carola & Baraka & Carola \\
\hline I & 2.00 & 2.00 & 3.0 & 2.0 & 77 & 75 \\
\hline II & 1.00 & 1.00 & 7.3 & 3.5 & 93 & 96 \\
\hline III & - & - & - & - & - & - \\
\hline IV & 4.00 & - & 1.6 & - & 73 & - \\
\hline V & 1.30 & 1.30 & 1.8 & 9.0 & 92 & 88 \\
\hline VI & 24.00 & 24.00 & 1.5 & 2.5 & 80 & 80 \\
\hline VII & 2.00 & 4.00 & 1.3 & 1.9 & 54 & 73 \\
\hline VIII & 3.30 & - & 1.08 & - & 67 & - \\
\hline IX & 16.00 & 16.00 & 18 & 20 & 87 & 90 \\
\hline
\end{tabular}

(-): failed isolation.

Photographs in (Figure 1, a-f) exhibit the fusion steps occurred between the two types of mesophyll protoplasts induced by electrical pulse.
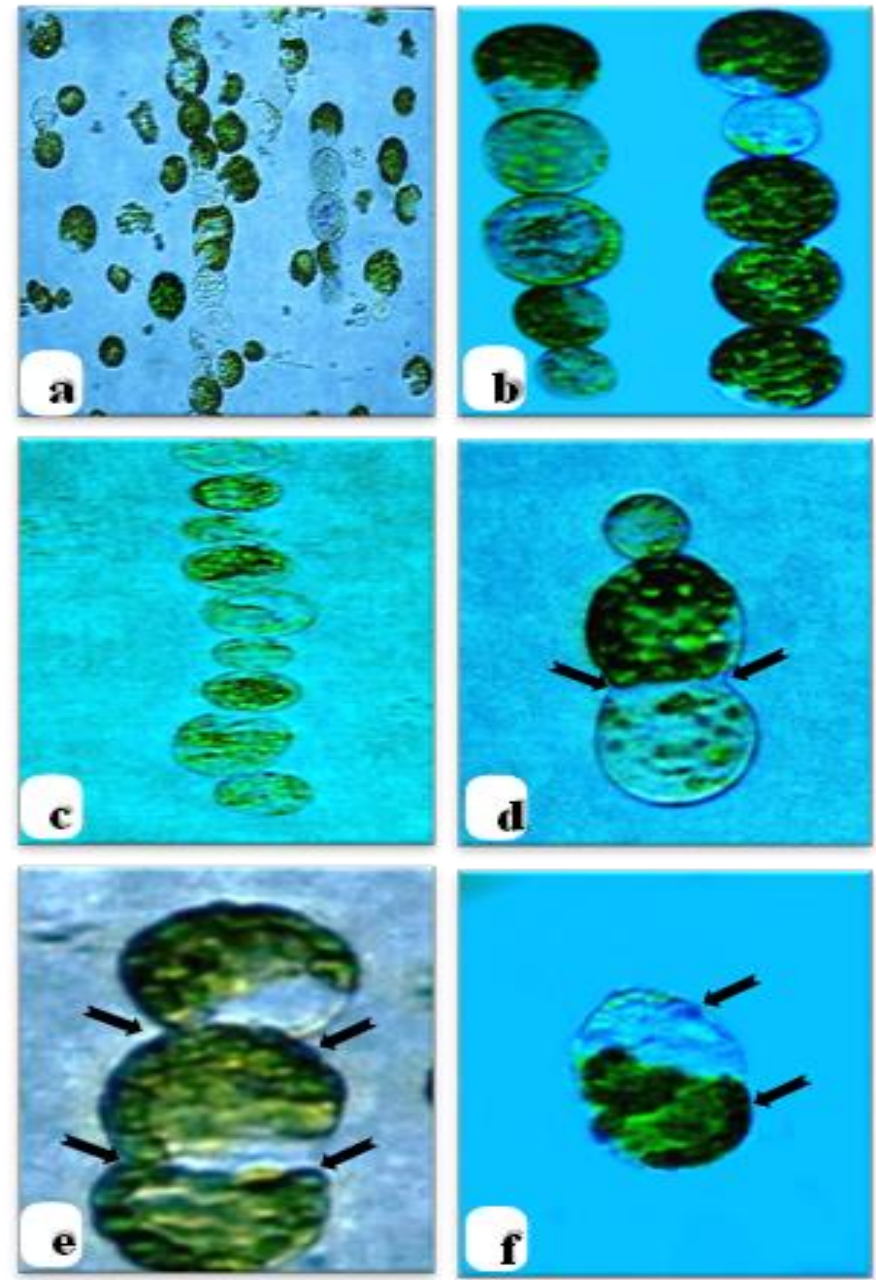

Figure 1. Steps of electrofusion between mesophyll protoplasts Baraka $x$ Carola varieties of sugar beet, Beta vulgaris L. a; Protoplasts mixture of the two varieties in single well of Petri-dish. b; Arrangement of protoplasts in (a) into short chains affected with a weak AC current. c; Arrangement of protoplasts into long chains found in other treatment with AC current. d; Occurrence of fusion between two protoplasts cells. Note the membranes lysis when DC current applied (Arrowed). e; Three cells fusion and membranes lysis (Arrowed). f; Single fusion product represented hybrid cell. Note the contents (Arrowed).

Accordingly fusion products (Figure 1, f) were picked-up based on their sizes and elongated shapes which differ from unfused protoplasts. The total number of the picked up fused cells was 247. However, their culture in agar drop was failed.

Table 4. Fusion products obtained from electrofusion between mesophyll protoplasts of Baraka $\times$ Carola varieties of sugar beet (Beta vulgaris L.).

\begin{tabular}{|c|c|c|c|}
\hline $\begin{array}{c}\text { Protoplasts } \\
\text { densities } \\
\left(\times 10^{4} \text { cell }\right. \\
\left.\mathrm{ml}^{-1}\right)\end{array}$ & Fusion conditions & $\begin{array}{c}\text { Fusion } \\
(\%)\end{array}$ & $\begin{array}{c}\text { No. of } \\
\text { fused cells }\end{array}$ \\
\hline 2.0 & $\begin{array}{c}1 \mathrm{MHz}, 1000 \mathrm{Vcm}^{-1}, 2 \text { pulses, } \\
1.5 \mathrm{msec}_{\text {/pulse }}\end{array}$ & 43 & 72 \\
\hline 3.0 & $\begin{array}{c}1 \mathrm{MHz}, 1000 \mathrm{Vcm}^{-1}, 2 \text { pulses, } \\
1.5 \mathrm{msec}^{-} / \mathrm{pulse}\end{array}$ & 49 & 77 \\
\hline 5.0 & $\begin{array}{c}1 \mathrm{MHz}, 1000 \mathrm{Vcm}^{-1}, 2 \text { pulses, } \\
1.5 \mathrm{msec} . / \mathrm{pulse}\end{array}$ & 73 & 98 \\
\hline \multicolumn{3}{|c|}{ Aggregate of fused cells } & 247 \\
\hline
\end{tabular}




\section{DISCUSSION}

The use of many enzyme mixtures is necessary to select the mixture suitable to produce a reasonable quantity of viable protoplasts (Bhojwani and Razdan, 1996). Although mesophyll protoplast was prevously isolated from sugar beet, only few studies are able to regenerate plants (Majewska-Sawka and Munster, 2003). Failing of fused protoplasts embedded in agar to divide could be due to the cell capability to start division under these conditions. Moreover, they might need specific requirements such as the addition of PSK (Phytosulfokin) to culture medium used in such protoplasts to stimulate the division of protoplasts (Grzebelus et al., 2012). Additionally, protoplasts density might be reason since the cultured density affected the cell wall regeneration and division (Davey et al., 2005).

Somatic hybridization technique followed in the present study through electrofusion between protoplasts of the two varieties Baraka $\times$ Carola could probably produce sugar beet plants of high - sugar content (Badr-Elden et al., 2010).

\section{V.CONCLUSION}

The results conclude that more efforts and trails are need to be applied in continuing this aimed investigation.

\section{ACKNOWLEDGEMENTS}

Thanks are due to Professor E. C. Cocking and Dr. Pual Anthony (Plant and Crop Sciences Division., Nottingham University, UK.) for their assistance. Many thanks also advices in using electrical fusion apparatus during our visit to PGMG Laboratories and to Dr. M. R. Davey (Nottingham University, UK) for providing us with new references used in writing up this manuscript.

\section{CONFLICT OF INTEREST}

The authors declare no conflict of interest.

\section{REFERENCES}

Al-Nema, Q.S., Al-Mallah, M.K. (2013). Protoplast isolation from leaf mesophyll of sugar beet Beta vulgaris L. axenic seedlings. J. Biotech. Res. Cent., 7, 36-42.

Arnon, D.I., Hoagland, D.R. (1944). The investigation of plant nutrition by artificial culture methods. Boil. Rev., 19, 55-67.

Badr-Elden, A., Ahmed, N., Nasr, M., Ibrahim, A. (2010). Isolation and fusion of protoplasts in sugar beet (Beta vulgaris L.). Sugar Tech., 12, 53-58

Bhojwani, S.S., Razdan, M.K. (1996). Plant Tissue Culture: Theory and Practice. A revised edition. Elsevier. India.

Davey, M.R. and Anthony, P. (2010). Plant Cell Culture Essential Methods. Wiley-Blackwell, UK.

Davey, M.R., Anthony, P., Patel, D., Power, J.B. (2010). Plant protoplasts: isolation, culture and plant regeneration. In: Davey, M.R. and P. Anthony, Plant Cell Culture Essential Methods. Wiley-Blackwell, UK. pp. 153-155.

Davey, M.R., Anthony, P., Power, J.B., Lowe, K.C. (2005). Plant protoplasts: status and biotechnological perspectives. Biotech. Adv., 23, 131-171.
Frearson, E.M., Power, J.B., Cocking, E.C. (1973). The isolation, culture and regeneration of Petunia leaf protoplasts. Dev. Biol., 33, 130-137.

Galbraith, D.W. (1981). The use of Calcofluor White to visualize cell walls. Bio/Technol., 3: 1104-1106. (C. F. Davey et al., 2010).

Grzebelus, E., Szklarczyk, M., Gren, J., Sniegowska, K., Jopek, M., Kacinska, I., Mrozek, K. (2012). Phytosulfokine stimulates cell division in sugar beet (Beta vulgaris L.) mesophyll protoplast cultures. Plant Growth Regul., 67, 93-100.

Guo, W.W., Deng, X.X., Yi, H.L. (2000). Somatic hybrids between novel orange (Citrus sinensis) and grapefruit (C. paradisi) for seedless triploid breeding. Euphytica, 116, 281-285.

Jones, B., lynch, P.T., Malaure, R.S., Handley, G.J., Blackhall, N.W., Hammatt, N., et al., (1994). Low cost equipment for the efficient large-scale electromanipulation of plant protoplasts. BioTechniques, $16,312-321$.

Kao, K.N. (1975). A Nuclear Staining Method for Plant Protoplasts. In: Gamborg, O.L. and Wetter, L.R. (eds). Plant Tissue Culture Methods. 60-61. National Research Council of Canada.

Majewska-Sawka, A., Munster, A. (2003). Cell wall antigens in mesophyll cells and mesophyll-derived protoplasts of sugar beet: possible implication in protoplast recalcitrance? Plant Cell Repts., 21, 946-954.

Mi Jeon, j., Ahn, N.Y., Son, B.H., Kim, C.Y., Han, C., Kim, G., et al., (2007). Efficient transient expression and transformation of PEGmediated gene uptake into mesophyll protoplasts of pepper (Capsicum annuum L.). Plant Cell, Tiss. Org. Cult., 88, 225-232.

Murashige, T., Skoog, F. (1962). A revised medium for rapid growth and bioassays with tobacco tissue culture. Physiol. Plant., 15, 473-497.

Niedz, R.P., Mckendree, W.L., Shatters, R.G. (2003). Electroporation of embryogenic protoplasts of sweet orange (Citrus sinensis L.) and regeneration of transformed plants. In vitro Cell. Dev. Biol. Plant., 39, 586-594.

Power, J.B., Cummins, S.E., Cocking, E.C. (1970). Fusion of isolated plant protoplasts. Nature, 225, 1016-1018.

Power, J.B., Davey, M.R., McLellan, M., Wilson, D. (1989). Laboratory Manual: Plant Tissue Culture. Plant Genetic Manipulation Group, University of Nottingham, UK.

Ritchie, G.A., Short, K.C., Davey, M.R. (1989). In vitro shoot regeneration from callus leaf axils and petioles of sugar beet (Beta vulgaris L.). J. Exp. Bot., 40, 277-283.

Rathore, K.S., Chowdhury, V.K., Hodges, T.K. (1993). Use of bar as a selectable marker gene and for the production of herbicide-resistant rice plants from protoplasts. Plant Mol. Biol., 21, 871-884.

Senda, M. Takeda, J. Abe, S., Nakamura, T. (1979). Induction of cell fusion of plant protoplasts by electrical stimulation. Plant Cell Physiol., 20, 1441-1443.

Szczerbakowa, A., Maciejewska, U., Zimnoch-Guzowska, E., Pawlowski, P., Skierski, S., Wielgat, B. (2001). Electrofusion of protoplasts from Solanum tuberosum, S. nigrum and S. bulbocastanum. Acta Physiol. Plant., 23, 169-179. 